William Steel

\title{
Responsible publication of criminal accusations in New Zealand - the case for change
}

Submitted for the LLB (Honours) Degree

Faculty of Law

Victoria University of Wellington

2013 
In 2000, a full Court of Appeal in Vickery v McLean excluded all generally published allegations of criminal conduct from the protection of Lange qualified privilege. Highlighting difficulties with the Court of Appeal's reasoning, this paper argues that New Zealand's current approach represents an unjustifiable limitation on the right to freedom of expression and is out of line with comparable jurisdictions. It suggests that adopting the principle from the recent UK Supreme Court decision in Flood v Times Newspapers Ltd, within the existing Lange framework, strikes a more appropriate balance between freedom of expression and the right to reputation. Doing so would allow Lange privilege to protect unproven, but verified, allegations of criminal impropriety whilst adequately safeguarding reputations and guarding against fears of trial by media.

Key words: Defamation, qualified privilege, criminal accusations, media 


\section{$\underline{\text { Table of Contents }}$}

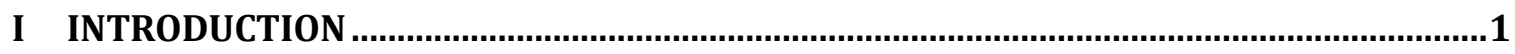

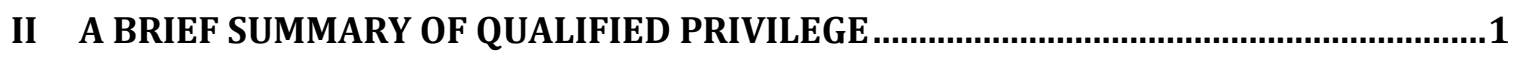

A THE CREATION OF A 'PUBLIC INTEREST' DEFENCE ..................................................................... 1

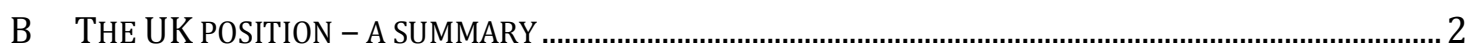

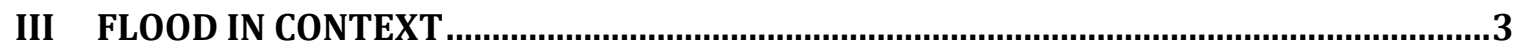

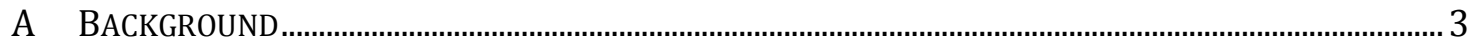

1 The facts................................................................................................................................... 3

2 The 'sting'......................................................................................................................................... 4

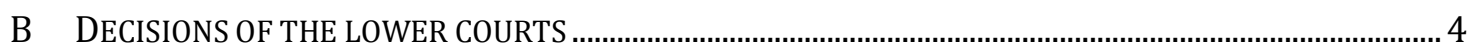

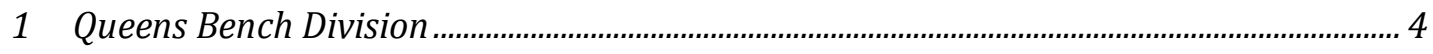

2 Court of Appeal.......................................................................................................................... 5

C THE SUPREME COURT ................................................................................................................... 6

1 The correct approach to Reynolds privilege ...................................................................... 7

2 Public interest in the detailed accusations.................................................................................. 8

3 Public interest in identifying DS Flood ........................................................................... 9

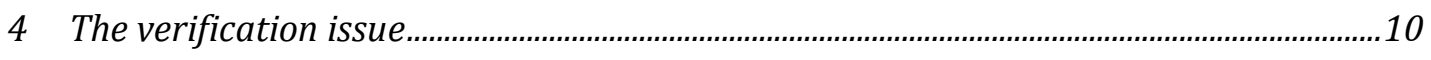

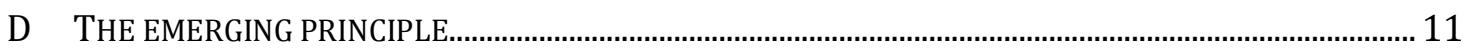

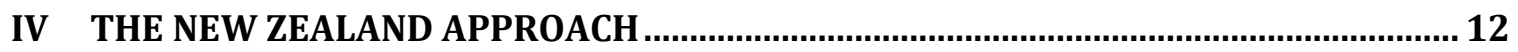

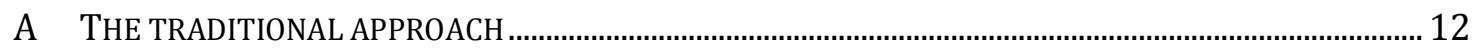

B LANGE V ATKINSON: THE GREAT LEAP FORWARD ........................................................................ 12

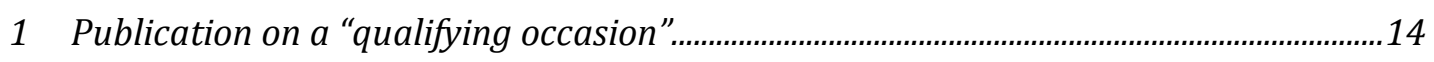

C PROCEDURAL DIFFERENCES - LANGE VS REYNOLDS ....................................................................... 14

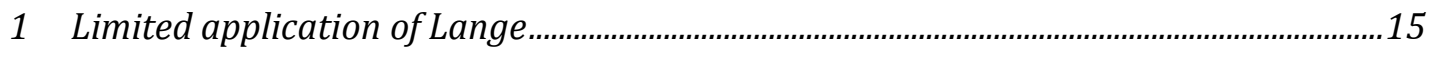

3 Establishing the defence ...........................................................................................................15

4 The importance of malice in New Zealand .........................................................................16

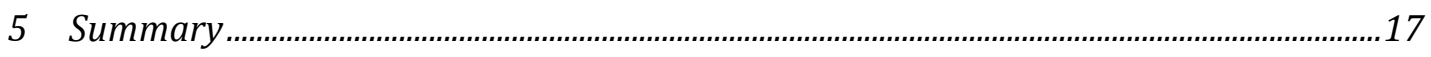

V CRIMINAL ACCUSATIONS IN NEW ZEALAND: VICKERY V MCLEAN........................... 18

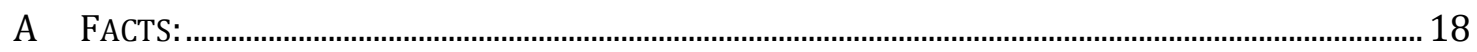

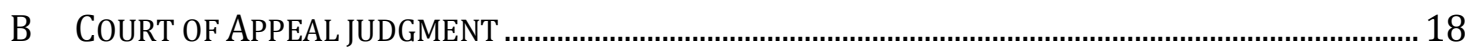

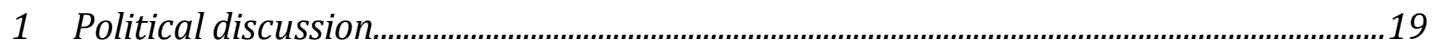

2 A 'non-qualifying' occasion .................................................................................................19

VI THE COURT OF APPEAL REVISITED

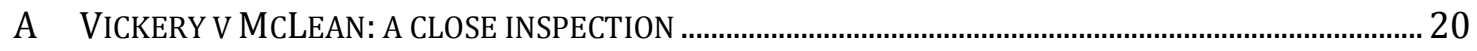

1 Precedent

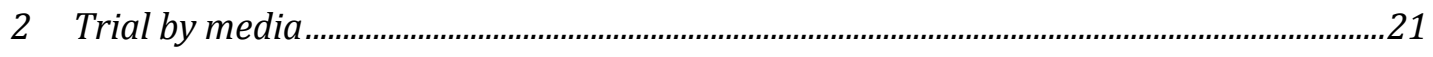

B HOW REALISTIC ARE TRIAL BY MEDIA FEARS? 


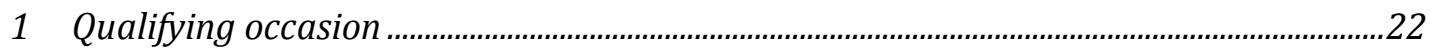

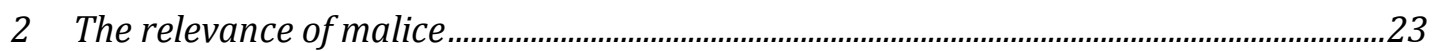

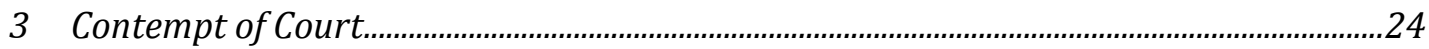

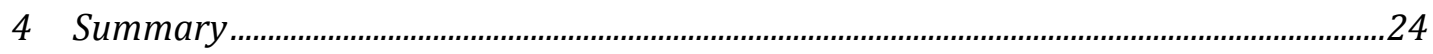

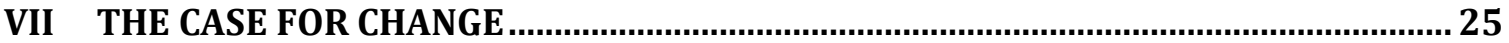

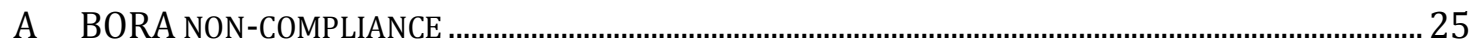

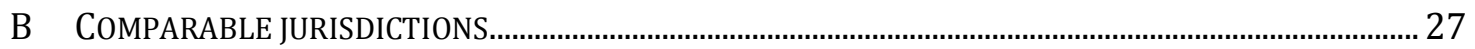

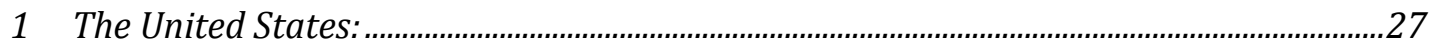

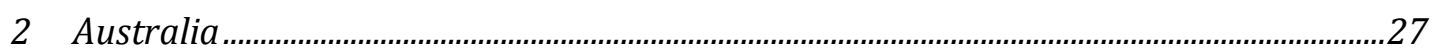

3 Canada

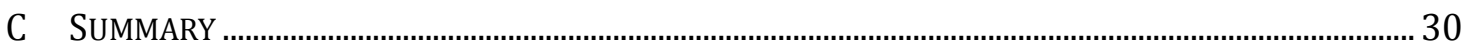

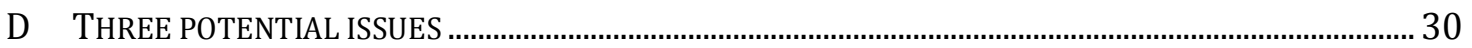

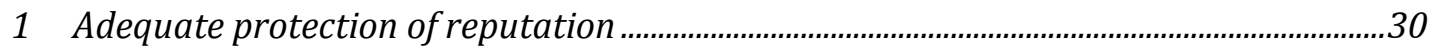

2 Interference with on-going police investigations..................................................................32

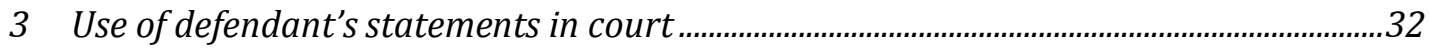

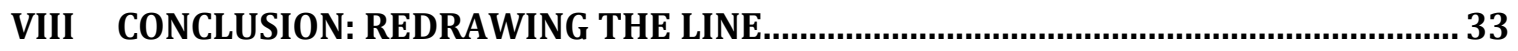

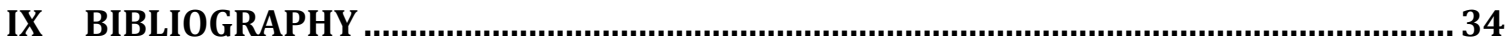

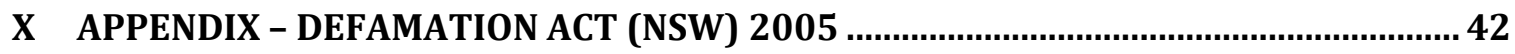




\section{Introduction}

The Court of Appeal's decision in Lange $v$ Atkinson ${ }^{1}$ represented a significant breakthrough for the media. Rebalancing the competing rights of protection of reputation and freedom of expression, the Court accepted that statements made generally were, in certain circumstances, capable of protection under qualified privilege. However, this expansionary approach was short-lived. Barely five months after its decision in Lange, a full Court of Appeal in Vickery v McLean ${ }^{2}$ excluded detailed allegations of criminal impropriety from the protection of the expanded defence.

In light of the recent UK Supreme Court decision in Flood v Times Newspapers, ${ }^{3}$ developments in comparable jurisdictions, and freedom of expression considerations, this paper argues for the revision of the Court of Appeal's decision in Vickery. In particular, it suggests that adopting the Flood principle, within the existing Lange framework, would bring New Zealand into line with comparable jurisdictions. Doing so would allow verified allegations of criminal conduct to be published whilst adequately protecting against trial by media.

\section{A brief summary of qualified privilege}

Although defamation protects an individual's reputation from unjustified attack, the law recognises that in certain, privileged, occasions, a plaintiff's right to reputation is subordinate to another's right to freedom of expression. ${ }^{4}$ On these limited occasions, publishers of defamatory statements are immune from defamation proceedings, unless the plaintiff can establish that the publisher acted with malice. ${ }^{5}$

\section{A The creation of a 'public interest' defence}

Traditionally, qualified privilege was limited to situations where the person communicating the defamatory statement had an interest or duty (legal, social or moral) to impart the information, and the recipient had a corresponding interest or duty to

\footnotetext{
${ }^{1}$ Lange v Atkinson [2000] 3 NZLR 385 (CA) [Lange 2000], reaffirming its earlier decision in Lange v Atkinson [1998] 3 NZLR 424 (CA) [Lange 1998].

${ }^{2}$ Vickery v McLean [2006] NZAR 481 (CA).

${ }^{3}$ Flood v Times Newspapers Ltd [2012] UKSC 11, [2012] 2 AC 273 [Flood].

${ }^{4}$ Lange 1998, above $\mathrm{n} 1$, at 472 per Tipping $\mathrm{J}$.

${ }^{5}$ The word "malice" is used loosely to describe s 19 of the Defamation Act 1992.
} 
receive it. ${ }^{6}$ This essential requirement of reciprocity necessarily limited the defence's applicability. Thus, while the New Zealand Court of Appeal accepted that the defence may apply where "some incidental publication to persons other than [those] having a legitimate interest to receive the communication could not reasonably be avoided", ${ }^{7}$ this concession was construed tightly. ${ }^{8}$

Accordingly, the decisions of the House of Lords in Reynolds $v$ Times Newspapers Ltd, ${ }^{9}$ and the New Zealand Court of Appeal in Lange ${ }^{10}$ were groundbreaking. Although the scope and applicability varied across the jurisdictions, the unifying feature in each decision was the expansion of the defence to cover (in certain circumstances) "statements which are published generally". ${ }^{11}$

\section{B The UK position - a summary}

In Reynolds, the House of Lords recognised a universal privilege designed to protect responsibly made statements concerning "matters of public concern". ${ }^{12}$ In Lord Nicholls' words: ${ }^{13}$

... the Reynolds privilege is concerned to provide a proper degree of protection for responsible journalism when reporting matters of public concern. Responsible journalism is the point at which a fair balance is held between freedom of expression on matters of public concern and the reputations of individuals. Maintenance of this standard is in the public interest and in the interest of those whose reputations are involved. It can be regarded as the price journalists pay in return for the privilege.

It is not enough for defendants to show that publication was in the public interest. Instead, they must also establish that their investigations and presentation of the story were "responsible". ${ }^{14}$ This is not a low standard. In assessing responsibility, courts will have

\footnotetext{
${ }^{6}$ Adam v Ward [1917] AC 309 (HL).

${ }^{7}$ Templeton $v$ Jones [1984] 1 NZLR 448 (CA) at 459.

${ }^{8}$ Stephen Todd and others The Law of Torts in New Zealand (6th ed, Thompson Reuters, Wellington, 2013) at 888 .

${ }^{9}$ Reynolds $v$ Times Newspapers Ltd [2001] 2 AC 127 (HL).

${ }^{10}$ Lange 1998, above n 1 . As modified by Lange 2000, above n 1.

${ }^{11}$ Lange 1998, above n 1, at 467.

12 Reynolds, above n 9, at 204.

${ }^{13}$ Bonnick v Morris [2002] UKPC 31, [2003] 1 AC 300 at 309.

${ }^{14}$ Reynolds, above n 9.
} 
regard to Lord Nicholls' "expressly non-exhaustive" ${ }^{15}$ list of ten factors. ${ }^{16}$ Consideration will be given to the seriousness of the allegation, the nature of the information and extent of its public interest, the journalist's sources (and his/her possible motivations), the journalist's subsequent verification, the urgency of publication, the tone of the article, and whether the plaintiff's comment was sought and his/her side of the story published.

\section{Flood in context}

It is in this light that one must consider Flood.

\section{A Background}

\section{The facts}

In December 2005, journalists working for Times Newspapers Limited (TNL) became aware of accusations made by an insider at ISC Global (a UK security firm). The insider, who had also approached the police, claimed that Detective Sergeant Flood, or his brother, had been providing information from the Metropolitan Police Service's (MPS's) extradition unit in return for money.

After a six-month investigation, The Times published an article on 2 June 2006 entitled "Detective accused of taking bribes from Russian exiles". It alleged that ISC made payments totalling $£ 20,000$ to "a recipient codenamed Noah ... who could be a reference to an officer in the extradition unit who was friendly with one of the ISC's bosses." 17 The article named the officer under investigation as DS Flood, before stating that his "home and office were raided last month", ${ }^{18}$ and that he had been temporarily removed from the extradition unit.

The allegations proved unfounded ${ }^{19}$ and proceedings for defamation were launched.

\footnotetext{
${ }^{15}$ Flood, above $\mathrm{n} 3$, at [113].

${ }^{16}$ Reynolds, above $\mathrm{n} 9$, at 205.

${ }^{17}$ Paragraph 5 of The Times article. See Flood v Times Newspapers Ltd [2009] EWHC 2375 (QB), [2010] EMLR 169 at [5].

${ }^{18}$ Paragraph 6 of The Times article. See Flood v Times Newspapers Ltd, above n 17, at [5].

${ }^{19}$ The MPS investigation was "unable to find any evidence to show that [the Claimant] ... has divulged any confidential information for monies or otherwise". See Flood v Times Newspapers Ltd, above n 17, at [4].
} 


\section{The 'sting'}

Taking a range of meanings approach, ${ }^{20}$ the Supreme Court held that some readers would have appreciated "that there were strong grounds for suspecting" DS Flood as guilty, while others would have simply accepted that there were grounds justifying a police investigation. ${ }^{21}$ The claim for Reynolds privilege was to be assessed on this basis.

\section{B Decisions of the lower courts}

\section{Queens Bench Division}

Concluding that "the conduct of police officers ... and police corruption in particular" 22 was a matter of "high public interest" ${ }^{23}$ Tugendhat $\mathbf{J}$ saw the availability of Reynolds privilege as a balancing exercise. ${ }^{24}$

On the one hand, the journalists' main motivation was to "ensure that an investigation took place, or that it took place in a timely fashion." 25 It followed that TNL should not be made to wait until the result of the police investigation. Moreover, although the evidence against DS Flood was circumstantial, weight must be given to the fact that the police had sufficient grounds to launch an investigation and execute a search warrant. ${ }^{26}$

On the other hand, Flood's reputation was irreparably damaged. Although the police had launched an investigation, the journalists knew that there was only a possibility that Flood had actually received bribes. ${ }^{27}$

Ultimately, Tugendhat $\mathrm{J}$ accepted that the article was "a proportionate interference" 28 with DS Flood's reputation, was justified due to its high degree of public interest and was

\footnotetext{
${ }^{20}$ Flood, above n 3, at [51] per Lord Phillips, [154] per Lord Mance. Lord Brown agreed at [111] and Lord Dyson accepted Lord Phillips' reasoning on this point at [190].

${ }^{21}$ Flood, above n 3, at [52].

${ }^{22}$ Flood v Times Newspapers Ltd, above n 17, at [131].

${ }^{23}$ At [216].

${ }^{24}$ At [199]-[219].

${ }^{25}$ At [200].

${ }^{26}$ At [204].

${ }^{27}$ At [210].

${ }^{28}$ At [216].
} 
"within the range of permissible editorial judgments which the court is required to respect." 29

\section{Court of Appeal}

On appeal, the Court of Appeal unanimously overturned Tugendhat J's finding of privilege. $^{30}$

Acknowledging that allegations of police corruption were in the public interest, the Court was concerned about the way in which they were presented. Had the article simply revealed that DS Flood was under investigation for bribery and gone no further, then, following the House of Lord's decision in Jameel, ${ }^{31}$ it would have been capable of protection. $^{32}$

However, the detailed allegations underlying the investigation formed the "whole story". ${ }^{33}$ These could only be protected if they were sufficiently verified. ${ }^{34}$ Engaging in an "almost surgical dissection" 35 of the article, the Court unanimously held that the allegations failed to meet this standard. ${ }^{36}$ The article comprised, in Lord Neuberger's words, "no more than unsubstantiated unchecked accusations, from an unknown source, coupled with speculation." ${ }^{37}$ Other members of the Court expressed similar sentiments. ${ }^{38}$ Accordingly, the Court reversed Tugendhat J's finding of qualified privilege.

The defining feature was the Court's discussion about whether Reynolds privilege could, in principle, apply to detailed allegations of criminal conduct.

While Lord Neuberger took the view that "nothing in principle prevents Reynolds privilege from protecting allegations of criminality", ${ }^{39}$ Moore-Bick and Moses LJJ took a

\footnotetext{
${ }^{29}$ At [217].

${ }^{30}$ Flood v Times Newspapers Ltd [2010] EWCA Civ 804, [2011] 1 WLR 153.

${ }^{31}$ Jameel $v$ Wall Street Journal Europe SPRL [2006] UKHL 44, [2007] 1 AC 359.

${ }^{32}$ At [100] per Moore-Bick LJ, [112] per Moses LJ, and [57] - [59] per Lord Neuberger.

${ }^{33}$ At [100].

${ }^{34}$ At [66] per Lord Neuberger, [102] per Moore-Bick LJ, and [116] per Moses LJ.

${ }^{35}$ Brian Dowrick "Investigating Corruption - Application of the Reynolds Defence to Print and On-Line Reports: Flood v Times Newspapers Ltd" (2010) 15 Comms L 116 at 118.

${ }^{36}$ At [67] - [76] per Lord Neuberger of Abbotsbury MR, [103] per Moore-Bick LJ and [116] per Moses LJ.

${ }^{37}$ At [73].

${ }^{38}$ At [103] per Moore-Bick LJ and [116] per Moses LJ.

${ }^{39}$ At [59].
} 
hard line. Moore-Bick LJ was particularly concerned with the ease with which criminal accusations may be made. This may be "out of malice, an excess of zeal or simple misunderstanding". ${ }^{40}$ Once made public, these accusations "are capable of causing a great deal of harm to the individual concerned". ${ }^{41}$ If the accusations had the effect of compelling the plaintiff to respond publicly "thereby depriving himself of the safeguard of the ordinary trial process and risking a measure of trial by press", Reynolds privilege will not attach. ${ }^{42}$ As Moses LJ noted, such an approach is appropriate because "once an accusation is dismissed, the blaring headline ... on page 1 becomes a tepid reference in the graveyard of page $2 . " 43$

Whilst this approach was strongly criticised, ${ }^{44}$ it set "Reynolds privilege in a new direction", ${ }^{45}$ bringing English defamation law more in line with the New Zealand Court of Appeal's decision in Vickery. ${ }^{46}$

\section{The Supreme Court}

Re-instating Tugendhat J's finding of privilege, the Supreme Court considered the Reynolds defence fully. In contrast to the House of Lords in Jameel, the Supreme Court in Flood considered Reynolds privilege to be sui generis. ${ }^{47}$

In doing so, the Supreme Court makes apparent what was previously assumed: Reynolds privilege is no longer constrained by traditional qualified privileged considerations. If publication concerns an issue of public interest, the question becomes whether it was published responsibly, rather than whether the circumstances justified publication. ${ }^{48}$ In

\footnotetext{
40 At [104].

41 At [104].

42 At [104].

43 At [119].

${ }^{44}$ See for example Paul Mitchell “The Nature of Responsible Journalism” (2011) 3 JML 19 at 27; Brian Dowrick "Some brief thoughts on public interest: Flood v Times Newspapers Limited" (2012) 17 Comms L 98; and Peter B Kutner "Suspicion, Investigation and Truth: A Continuing Evolution in English Defamation Law" (2011) 3 JML 61 at 83.

${ }^{45}$ Mitchell, above n 44, at 20.

${ }^{46}$ Vickery, above n 2.

${ }^{47}$ Flood, above n 3, at [38]. See also [113] per Lord Brown, [126] per Lord Mance, and [188] per Lord Dyson. This answered a question posed by Loutchansky v Times Newspapers Ltd (Nos 2 - 5) [2001] EWCA Civ 1805, [2002] QB 783 at [35].

48 At [38]. See also Loutchansky v Times Newspapers Ltd, above n 47, at [36].
} 
stark contrast to the New Zealand position, this "leaves little or no room for the separate consideration of malice". 49

\section{The correct approach to Reynolds privilege}

Their Lordships differed on the correct approach to Reynolds privilege.

For Lords Brown and Clarke, the overarching consideration was: ${ }^{50}$

... whether those who published the defamation, given what they knew and did not know and whatever they had done or had not done to guard so far as possible against the publication of untrue defamatory material, could properly have considered the publication in principle to be in the public interest.

This single-issue test, resonant of Moore-Bick LJ's approach in the Court of Appeal, ${ }^{51}$ subsumes issues of responsible journalism within the concept of public interest. The difficulty with this test is that it fails to consider expressly whether publication was "responsible". Nor does it make any mention of Lord Nicholls' ten factors from Reynolds. ${ }^{52}$ Whilst it is fair to assume that these considerations will form part of the Court's assessment, the adoption of such an approach may result in courts placing greater attention on the subject matter at issue, rather than the journalist's conduct. ${ }^{53}$

In contrast, the majority maintained the conventional two-step approach. ${ }^{54}$ Courts must consider first, whether the publication as a whole, including the defamatory allegations, was in the public interest and, secondly, whether the steps taken by the journalist (or other publisher) amounted to "responsible journalism". Both steps remain vital. ${ }^{55}$

\footnotetext{
${ }^{49}$ Flood, above n 3, at [38]. For further discussion of this point see below: Section IV Part C Subpart 4: The importance of malice in New Zealand.

${ }^{50}$ At [113] per Lord Brown, [184] per Lord Clarke.

${ }^{51}$ Flood v Times Newspapers Ltd, above n 30, at [101] where Moore-Bick LJ held, "[i]n my view ... it is not possible to decide whether the publication was in the public interest without some consideration of the question of responsible journalism." Thus, "if the inclusion of the defamatory material was justifiable, so was the story, and vice versa."

${ }^{52}$ Reynolds, above $\mathrm{n}$ 9. These factors are set out above in Section II Part B: The UK position - a summary.

${ }^{53}$ Eric Barendt "Reynolds Privilege and Reports of Police Investigations" (2012) 4 JML 1 at 5.

${ }^{54}$ At [188] per Lord Dyson. Lords Mance and Phillips both adopted a two-tier approach in their judgments.

${ }^{55}$ Barendt, above $\mathrm{n} 53$, at 5.
} 
Although the majority's approach helpfully separates journalist's actions from the article's public interest, it is important to remember Lord Dyson's remark that one will often merge into the other. Thus, while "factually distinct ... the rationale for Reynolds privilege tends to conflate them." 56 Against this background, one must consider their Lordships' reasoning.

\section{Public interest in the detailed accusations}

While their Lordships were united in the view that issues of police corruption were of "great public interest and sensitivity", 57 their reasoning thereafter was fractured, exposing significant disagreement.

Most notably, Lord Brown struck a hard line requiring TNL to show that it was in the "public interest that the public should know, in advance of the outcome of the investigation, that such an allegation has been made and is being duly investigated." 58 Expressing strong reservations, he accepted, on the facts, that this burden was satisfied. ${ }^{59}$

Although not going as far as Lord Brown, Lord Phillips also expressed strong reservations, holding that the factors set out by Moore-Bick LJ in the Court of Appeal "will often weigh conclusively against publication". ${ }^{60}$ However, he was prepared to accept that, on the facts of this case, the public interest "lay not merely in the fact of police corruption, but in the nature of that corruption." ${ }^{61}$ On this basis, coupled with the journalist's desire to ensure that an investigation was pursued, Lord Phillips accepted that publication of the allegations was in the public interest. ${ }^{62}$

Lords Phillips' and Brown's reluctance can be strongly contrasted to the approach of both Lords Mance and Dyson, with whom Lord Clarke expressed agreement. ${ }^{63}$ In adopting an

\footnotetext{
${ }^{56}$ At [189].

${ }^{57}$ At [179] per Lord Mance. See also [68] per Lord Phillips, [119] per Lord Brown, [185] per Lord Clarke, and [195] per Lord Dyson.

${ }^{58}$ At [115].

${ }^{59}$ At [119].

${ }^{60}$ At [68]. Referring to Flood v Times Newspapers Ltd, above n 30, at [104]. See above: Section III Part B Subpart C: The Court of Appeal.

${ }^{61}$ At [68].

${ }^{62}$ At [69].

${ }^{63}$ Lord Clarke expressed agreement at [184].
} 
expansive approach designed to remove the chilling effect that strict adherence to MooreBick LJ's considerations would provoke, ${ }^{64}$ both stressed that whilst: ${ }^{65}$

[t]he courts must have the last word in setting the boundaries of what can properly be regarded as acceptable journalism ... within those boundaries the judgment of responsible journalists and editors merits respect.

Their Lordships considered that publication of a bare statement that DS Flood was being investigated for corruption was unlikely to be published. ${ }^{66}$ Although not conclusive, it strongly influenced their finding that publication of the detailed allegations was in the public interest.

Finally, both Lords Mance and Dyson distinguished between accusations made against public and private individuals. ${ }^{67}$ Whilst the dangers of trial by press weigh heavily against publication of the details of an allegation against an ordinary person, Lord Dyson held that the same considerations are inapplicable to those performing public functions in office. ${ }^{68}$ With the exception of Lord Phillips, ${ }^{69}$ their Lordships were unanimous that, as a public officer performing an important function, DS Flood must expect close scrutiny from the press. ${ }^{70}$ Accordingly, the majority accepted that publication of the detailed allegations was in the public interest.

\section{Public interest in identifying DS Flood}

Although the Court unanimously held that publication of DS Flood's name was in the public interest, this was not automatic. Indeed, for Lord Phillips, "had it been possible to conceal Sergeant Flood's identity by removing his name from the article, together with the reference to Noah, but otherwise leaving it intact" publication of DS Flood's name would not have been in the public interest. ${ }^{71}$

\footnotetext{
${ }^{64}$ At [193].

${ }^{65}$ At [137] per Lord Mance (emphasis added), [194] per Lord Dyson.

${ }^{66}$ At [170] per Lord Mance. Lord Clarke expressed agreement at [184], as did Lord Dyson at [190].

${ }^{67}$ At [178] per Lord Mance, [195] per Lord Dyson. Lord Clarke agreed at [184].

68 At [195].

69 At [73].

70 At [119] per Lord Brown, [178] per Lord Mance, [185] per Lord Clarke, and [195] per Lord Dyson.

${ }^{71}$ At [73].
} 
On the facts, that was not possible. Without the 'colour' added by DS Flood's name, the article was unlikely to be "readable or publishable". ${ }^{72}$ In such a state, the article would not be able to fulfil its task of ensuring a thorough police investigation. ${ }^{73}$

Moreover, an anonymous article would have simply spread the blame across the entire extradition unit. ${ }^{74}$ In such circumstances, their Lordships accepted that it was in the public interest to name the officer under investigation. ${ }^{75}$

\section{The verification issue}

Reynolds privilege is only available to defendants when criminal accusations made against third parties are sufficiently verified. ${ }^{76}$ This verification duty depends on the nature of the allegations. Where (as in Flood) the defendant asserts that there were reasonable grounds to suspect the claimant committed an offence, the journalist "should be reasonably satisfied both that the supporting facts were true and that there was a serious possibility" of guilt. ${ }^{77} \mathrm{He}$ would not, however, have to "satisfy himself, on reasonable grounds, that the claimant had in fact been guilty" which would be the case if the article asserted DS Flood's guilt. ${ }^{78}$

The Supreme Court unanimously accepted that TNL met this standard. ${ }^{79}$ The information provided by the unidentified (but not unknown ${ }^{80}$ ) insider presented a strong circumstantial case, further supported by the known friendship between DS Flood and Mr Hunter of ISC. ${ }^{81}$ The article was "balanced in content and tone ... did not assert the truth of the

\footnotetext{
${ }^{72}$ At [169] per Lord Mance. Similar sentiments were expressed at [113] per Lord Brown and [199] per Lord Dyson. Lord Clarke agreed at [184].

${ }^{73}$ At [169] per Lord Mance. See also [199] per Lord Dyson, with whom Lord Clarke agreed at [184].

${ }^{74}$ At [74] per Lord Phillips, [113] per Lord Brown, [169] per Lord Mance. Lords Clarke and Dyson agreed at [184] and [190] respectively.

${ }^{75}$ At [74] - [75] per Lord Phillips, [113] per Lord Brown, [169] per Lord Mance, and [199] per Lord Dyson. Lord Clarke agreed with Lords Mance and Dyson at [184].

${ }^{76}$ See above, Section II Part B: The UK position - a summary.

${ }^{77}$ At [81] per Lord Phillips (emphasis added). Lord Dyson agreed at [190]. Lord Clarke agreed with Lord Dyson at [184].

${ }^{78}$ At [79] per Lord Phillips. Lord Dyson agreed at [190]. Lord Clarke agreed with Lord Dyson at [184].

${ }^{79}$ At [82] - [97] per Lord Phillips, [119] per Lord Brown, and [161] - [167] per Lord Mance, with whom Lords Clarke and Dyson agreed at [184] and [190] respectively.

${ }^{80}$ In the Court of Appeal, the ISC insider was referred to as unknown. In the Supreme Court, both Lords Phillips and Mance stressed that the insider was known, but not identified.

${ }^{81}$ At [96] per Lord Phillips.
} 
reported allegations and all those implicated were given the opportunity to comment, and their denials were published." 82 Finally, whilst there was a risk that the ISC insider had an 'axe to grind' he had given information to the police who, when questioned, acknowledged an on-going investigation into DS Flood's actions. ${ }^{83}$ In such circumstances, the journalists were entitled to infer that the police "had concluded that the accusation made against Sergeant Flood might be well founded." 84

\section{The emerging principle}

In upholding TNL's appeal, the Supreme Court accepted that, in certain circumstances, it is in the public interest to allow the detailed publication of criminal accusations made against a named individual prior to, or contemporaneous with, any police investigation. ${ }^{85}$ However, this is not a decision of general applicability. "Each case turns on its own facts." 86 The Supreme Court simply allows the possibility that, by analogy, other cases may fit within the Flood 'exception'. Several points will influence this.

Overriding the application of Reynolds privilege is the requirement that publication is in the public interest. Importantly the majority distinguished between accusations made against public and private individuals. ${ }^{87}$ While public officers "must expect that their conduct will be open to close scrutiny by the press", ${ }^{88}$ the same cannot, implicitly, be said about private individuals. ${ }^{89}$ Subject to the majority's deference to editorial discretion, it is likely that Moore-Bick LJ's considerations will often "weigh conclusively against publication" 90 of allegations made against private individuals. ${ }^{91}$

\footnotetext{
82 At [180] per Lord Mance.

${ }^{83}$ At [96] per Lord Phillips.

${ }^{84}$ At [95] per Lord Phillips. See also [163] per Lord Mance.

${ }^{85}$ See, for example, Lord Brown's statement of the issue at [94]: "can [it] ever properly be said to be in the public interest to publish, as here, the detailed allegations underlying a criminal investigation - to publish, in effect, a summary of the case against the suspect, reliant in part on anonymous sources, before even the police have investigated the allegations, let alone charged the suspect." The Court resoundingly answered "yes".

${ }^{86}$ At [68] and [75].

87 At [178] per Lord Mance, [195] per Lord Dyson. Lord Clarke agreed at [184].

88 At [178].

${ }^{89}$ At [195] per Lord Dyson. This is supported by Lord Phillips at [68] and Lord Brown at [115] - [119].

90 At [68].

${ }^{91}$ At [68] per Lord Phillips, [195] per Lord Dyson, and [115] - [119] per Lord Brown.
} 
Accordingly, publication of serious criminal accusations is capable of protection under Reynolds privilege if they are sufficiently verified and, having regard to editorial discretion, are in the public interest.

\section{The New Zealand approach}

Before considering the applicability of the Flood principle in New Zealand, one must consider New Zealand's approach to qualified privilege, focusing on the underling differences between Reynolds and Lange qualified privilege.

\section{A The traditional approach}

Traditionally, qualified privilege was limited by the duty/interest test in Adam v Ward. ${ }^{92}$ Early attempts to expand the defence's application to general publication were refused because "the public has no interest beyond idle curiosity in knowing the information, or because the media have no duty to purvey rumour or inaccurate information."93

Although the door was never closed to such arguments, it took an exceptional case to prise it open.

\section{B Lange $v$ Atkinson: the great leap forward}

In an article published by North and South magazine, Mr Atkinson, a political scientist, compared David Lange (a former New Zealand Prime Minister) unfavourably to his predecessors. An accompanying cartoon reinforced the accusations of memory lapses and hypocrisy. Mr Lange brought an action in defamation.

In a "ground breaking judgment", 94 Elias $\mathrm{J}$ upheld the defence of qualified privilege, recognising an extension for political discussion. ${ }^{95}$ On appeal, the Court of Appeal accepted that qualified privilege could apply to generally published defamatory remarks. The crux of the Court's judgment was a five-point summary of the principles governing the extended privilege. ${ }^{96}$

\footnotetext{
${ }^{92}$ Adam $v$ Ward, above n 6.

93 Todd, above n 8 , at 887.

94 W. R. Atkin "Defamation Law in New Zealand 'Refined' and 'Amplified"” (2001) Common Law World Review 237 at 241.

95 Lange v Atkinson [1997] 2 NZLR 22 (HC) at 51.

96 Lange 1998, above n 1, at $467-468$.
} 
Several objections were raised to the Court of Appeal's formulation. ${ }^{97}$ In particular, read literally, the Court appeared to condone any defamatory remark made against a politician - regardless of the underlying circumstances. ${ }^{98}$

On appeal, the Privy Council (comprising the same five-member board which decided Reynolds) accepted that differing local circumstances made it inappropriate for them to substitute a ruling. ${ }^{99}$ The case was sent back to the Court of Appeal.

In what has been labelled a "bizarre" 100 decision, the Court, citing constitutional and socio-economic differences, rejected the English approach in Reynolds, favouring an amended version of their original decision. The principles were summarised as follows: ${ }^{101}$

Our consideration of the development of the law leads us to the following conclusions about the defence of qualified privilege as it applies to political statements which are published generally:

1. The defence of qualified privilege may be available in respect of a statement which is published generally.

2. The nature of New Zealand's democracy means that the wider public may have a proper interest in respect of generally-published statements which directly concern the functioning of representative and responsible government, including statements about the performance or possible future performance of specific individuals in elected public office.

3. In particular, a proper interest does exist in respect of statements made about the actions and qualities of those currently or formerly elected to Parliament and those with immediate aspirations to such office, so far as those actions and qualities directly affect or affected their capacity (including their personal ability and willingness) to meet their public responsibilities. ${ }^{102}$

\footnotetext{
${ }^{97}$ See for example, Todd, above n 8, at 890 and Law Commission Defaming Politicians: A Response to Lange v Atkinson (NZLC, PP33, 1998).

${ }^{98}$ Todd, above $\mathrm{n} 8$, at 890 .

${ }^{99}$ Lange v Atkinson [2000] 1 NZLR 257 (PC).

${ }^{100}$ Atkin, above $\mathrm{n} 94$, at 242.

${ }^{101}$ Lange 1998, above n 1, at 467 - 468, as updated by Lange 2000, above n 1, at [41].

${ }^{102}$ Following Lange 2000 this has now been significantly watered down. In particular, the Court, at [13], stressed that its 1998 judgment "was not intended to remove from the assessment whether the occasion is privileged an inquiry into the circumstances or context of the publication." The change is aptly summarised by Bill Atkin and Steven Price in "Lange 2000" [2000] NZLJ 236 where they note at 236: "'Does exist' in 1998 means 'may exist' in 2000".
} 
4. The determination of the matters which bear on that capacity will depend on a consideration of what is properly a matter of public concern rather than of private concern.

5. The width of the identified public concern justifies the extent of the publication.

6. To attract privilege the statement must be published on a qualifying occasion.

\section{Publication on a "qualifying occasion"}

Importantly, the Court qualified its earlier decision, introducing a requirement that publication be made on a "qualifying occasion." ${ }^{103}$ In the Court's words, consideration of whether publication is capable of protection requires an examination of the "circumstances or context of the publication." ${ }^{104}$ Regard must be had to "matters such as the identity of the publisher, the context in which the publication occurs, and the likely audience, as well as the actual content of the information."105

The Court illustrated this requirement through the following example: ${ }^{106}$

$\ldots$ it is questionable whether a one-line reference to alleged misconduct of a grave nature on the part of a parliamentary candidate reflecting on his or her suitability, appearing in an article in a motoring magazine about that person's activities in motor sport, should receive protection. By contrast, the inclusion of such material in the course of a lengthy serious article on a coming election may justifiably attract the protection.

Beyond this pithy statement, the Court offered little guidance on what circumstances and contexts will be relevant. ${ }^{107}$ However, this limitation's significance was revealed five months later in the Court of Appeal's decision in Vickery $v$ McLean. ${ }^{108}$

\section{Procedural differences - Lange vs Reynolds}

\footnotetext{
${ }^{103}$ Lange 2000, above n 1, at [41].

${ }^{104}$ Lange 2000, above n 1, at [13].

${ }^{105}$ Lange 2000, above n 1, at [13].

${ }^{106}$ Lange 2000, above $\mathrm{n} 1$, at [13].

${ }^{107}$ For a detailed discussion of the Court's reasoning on this point see John Burrows "Lange v Atkinson 2000: Analysis" [2000] NZ Law Review 389 at 393.

${ }^{108}$ Vickery, above n 2.
} 
Although one commentator remarked shortly after Lange 2000 that "New Zealand law is now not that far removed" 109 from the English position, two key differences remain.

\section{Limited application of Lange}

First, the Court of Appeal limited Lange privilege to statements concerning "representative and responsible government". ${ }^{110}$ Rejecting the House of Lords' approach in Reynolds, the Court emphasised that Lange privilege is "less about the press and rather more about the constitutional right of all New Zealanders to participate in the discussion and evaluation of their own political leaders." "111 Although subsequent interpretation by the High Court has been expansionary, ${ }^{112}$ the Lange extension remains grounded in its link to representative government.

By contrast, the House of Lords expressly rejected such a narrow approach, holding that "it would be unsound in principle to distinguish political discussion from discussion of other matters of serious public concern." ${ }^{113}$ Reynolds privilege is universal. Subject to considerations of "responsible journalism", the defence is capable of attaching to any statement, on any topic or about any person.

\section{The underlying frameworks: a comparison}

Secondly, the defences are structurally different. Whilst Reynolds privilege leaves "little or no room for the separate consideration of malice", ${ }^{114}$ the Court of Appeal in Lange placed significant emphasis on its statutory equivalent. This divergence has substantially altered the respective frameworks.

\section{Establishing the defence}

\footnotetext{
109 Atkin, above n 94, at 242.

${ }^{110}$ Lange 2000, above n 1, at [41]. However, many commentators have argued that the defence is far broader and extends beyond discussion of national politicians. See for example Burrows, above $\mathrm{n}$ 107, at 391 - 392; JF Burrows and Ursula Cheer Media Law in New Zealand (6th ed, LexisNexis, Wellington, 2010) at 127 and Todd, above $\mathrm{n} 8$, at 893.

111 Lange 2000, above n 1, at [33].

112 See for example Osmose New Zealand v Wakeling [2007] 1 NZLR 841 (HC); Lee v The New Korea Herald Ltd HC Auckland CIV-2008-404-5072, 9 November 2010; and Dooley v Smith [2012] NZHC 529.

${ }^{113}$ Reynolds, above n 9, at 204.

${ }^{114}$ Flood, above n 3, at [38].
} 
In both jurisdictions, the defendant bears the burden of establishing the respective privilege defence. However, the similarities end there.

In New Zealand, a prima facie defence is easily established. Defendants must simply show that the publication was made on a qualifying occasion and concerned a matter of representative and responsible government. As the Court of Appeal acknowledged, "[a]ny bona fide communication in the course of political discussion ... is very likely to be made on an occasion of qualified privilege." 115 Examination of the circumstances leading to publication, such as the efforts journalists took to verify the allegations are considered under the second stage of the inquiry. ${ }^{116}$

In contrast, Reynolds privilege is determinatively won or lost at this first stage. As previously noted, ${ }^{117}$ English defendants must satisfy two criteria. First, publication must be in the public interest. Secondly, journalists must establish that their investigations and presentation of the story was responsible. As Flood reveals, this is not a low standard.

Importantly, where journalists have satisfied the responsible publication requirements, it would be extremely difficult for a plaintiff to argue that the journalists did not believe what they were saying was true. In this sense, "little scope remains for any subsequent finding of malice." 118

Journalists in the UK face an uphill battle. For Reynolds privilege to be established they must prove that their investigations were thorough, based on relatively sound evidence, and that they accurately presented the information in an unbiased tone. In contrast, so long as publication was made on a qualifying occasion and relates to representative and responsible government, Lange privilege is prima facie established.

\section{The importance of malice in New Zealand}

Because a prima facie defence is relatively easily established under the Lange framework, the primary focus in New Zealand revolves around the plaintiff's attempts to characterise the publication as 'malicious'. ${ }^{119}$ This is important. Whereas English defendants must

\footnotetext{
${ }^{115}$ Lange 2000, above n 1, at [21].

116 Burrows and Cheer, above n 110, at 127.

${ }^{117}$ For a more detailed consideration of the English approach see above - Section II Part B: The English Approach - a summary.

${ }^{118}$ Loutchansky, above n 47, at [30]. See also Flood, above n 3, at [38].

${ }^{119}$ Note, the word "malicious" in this context is used loosely to describe s 19 of the Defamation Act 1992.
} 
prove that they acted responsibly, under Lange, the plaintiff faces the "notoriously difficult" ${ }^{120}$ burden of establishing statutory malice.

Plaintiffs must prove that "the defendant was predominantly motivated by ill will ... or otherwise took improper advantage of the occasion of publication." ${ }^{121}$ Ironically, the Court is likely to assess "improper" publication with reference to the UK's post-Reynolds case law. ${ }^{122}$ The more serious the allegations and the broader the audience, the more likely a court will find an "improper" use of the privilege. ${ }^{123}$

Unfortunately, there have been few New Zealand cases on Lange qualified privilege, making it difficult to compare the effects of these contrasting burdens empirically. Nevertheless, for the reasons provided by Professor Atkin, it is submitted that the English approach is preferable. ${ }^{124}$ As Professor Burrows notes, "the unitary test of Reynolds is altogether cleaner and easier to apply."125

\section{Summary}

Reynolds and Lange were correctly regarded as groundbreaking decisions, opening the door for qualified privilege's application to general publication. However, when

\footnotetext{
${ }^{120}$ Rosemary Tobin "Political Discussion in New Zealand: Cause for Concern?" [2003] NZ Law Review 215 at 225.

${ }^{121}$ Defamation Act 1992, s 19.

${ }^{122}$ It must, however, be acknowledged that this has never been confirmed by the courts. Nevertheless, two key passages in Lange 2000, above n 1, suggest that the Reynolds factors may be relevant. First, at [42], the Court stressed that "[t]he purpose of the newly-recognised privilege is to facilitate responsible public discussion of the matters which it covers. If the privilege is not responsibly used, its purpose is abused and improper advantage is taken of the occasion." (emphasis added). Secondly, at [47] the Court expanded on this statement, holding that "It is within the concept of misusing the occasion ... if there has been a failure to give such responsible consideration to the truth or falsity of the statement as the jury considers should have been given in all the circumstances."

${ }^{123}$ Lange 2000, above $\mathrm{n} 1$, at [48].

${ }^{124}$ Atkin, above n 94, at 251 - 252. In particular, Professor Atkin raised two issues with the Court of Appeal's current formulation. First, plaintiffs will often "struggle" to show that the defendant acted irresponsibly given the newspaper rule, and the s 41 Defamation Act 1992 requirement to provide pre-trial particulars. Secondly, accepting that a jury is well qualified to assess whether the publisher was motivated by ill-will, he argued that questions of "what amounts to responsible journalism, how it might impact on the public interest, and whether publication is justified in the interests of freedom of speech are far less obviously jury matters." In the end Professor Atkin concluded: "Where New Zealand differs, the outcome is not very satisfactory. New Zealand might have been wiser simply to have followed Reynolds."

125 John Burrows "Media Law” [2002] NZ Law Review 217 at 221.
} 
considering the application of the Flood principle in New Zealand the fundamental differences between the respective jurisdictions must be remembered.

\section{$V$ Criminal accusations in New Zealand: Vickery v McLean}

In its only judgment on qualified privilege since Lange, a five-member Court of Appeal definitively excluded allegations of criminal activity from Lange privilege.

\section{A Facts:}

Mr Vickery, Chairman of the Papakura Ratepayers Association, became concerned over a Papakura District Council proposal to outsource the District's water and wastewater services to a French company - Generale Des Eaux. After hearing reports of possible corruption scandals involving Generale overseas, Vickery took the view that the tender was a "jack up". He complained to the Ombudsman and the Auditor-General. Whilst the Ombudsman refused to investigate, the Auditor-General considered the allegations, but found no suggestion of impropriety. ${ }^{126}$

Unsatisfied, "Mr Vickery became increasingly strident", ${ }^{127}$ eventually laying a complaint with the Serious Fraud Office (SFO). Matters came to a head following a letter Vickery sent to three newspapers, including the New Zealand Herald. This letter referred to his complaint to the SFO, then noted that "[t]here was serious enough circumstantial evidence to suggest that criminal irregularity may have taken place." 128 The SFO later dismissed this complaint.

Three senior Council executives commenced defamation proceedings. Their claim was upheld in the High Court. ${ }^{129}$ Vickery appealed, relying on the defence of qualified privilege.

\section{B Court of Appeal judgment}

The Court of Appeal dismissed Vickery's application for two reasons.

\footnotetext{
126 Vickery, above n 2, at [3].

127 At [4].

128 At [5].

${ }^{129}$ McLean and Others $v$ Vickery HC Auckland CP 283/97, 29 May 2000.
} 


\section{Political discussion}

In a controversial decision, ${ }^{130}$ the Court concluded that, because Vickery's letter targeted senior Council executives rather than elected counsellors, it could not "sensibly be regarded as political discussion". ${ }^{131}$ It was therefore outside the scope of Lange protection.

\section{A 'non-qualifying' occasion}

More importantly, even if Vickery could bring his comments within the Lange framework, the Court took the view that this was not a "qualifying occasion", and was therefore incapable of protection.

Revealing the importance of Lange's sixth qualification, ${ }^{132}$ the Court held that bona fide allegations of criminal behaviour are only capable of protection when made to authorities with a responsibility to investigate and, if appropriate, to act upon them. ${ }^{133}$ Definitively limiting the scope of Lange privilege, the Court held: ${ }^{134}$

It is ... demonstrably not in the public interest to have criminal allegations, even if bona fide and responsibly made, ventilated through the news media. That could only encourage trial by media and associated developments which would be inimical to criminal justice processes. Society has mechanisms for investigating crime and determining guilt or innocence. It is not in the public interest that these mechanisms be bypassed or subverted.

\section{The Court of Appeal revisited}

Given such strong statements of principle, an initial reading of the Court's judgment leads to the conclusion that Flood is wholly irrelevant in New Zealand. Nevertheless, on a detailed analysis, the issue is not so clear-cut.

\footnotetext{
${ }^{130}$ See for example Todd, above n 8, at 915; Burrows and Cheer, above n 110, at 127; and Atkin, above n 94, at 243.

131 At [17].

${ }^{132}$ See above, Section IV Part B: Lange v Atkinson: the great leap forward.

${ }^{133}$ At [17].

${ }^{134}$ At [19].
} 


\section{A Vickery v McLean: a close inspection}

Underlying the Court's refusal to extend Lange privilege to criminal accusations were two considerations: precedent and fears of trial by media. In the author's opinion neither consideration provides sufficient support for the Court's ruling.

\section{$1 \quad$ Precedent}

The Court relied upon two decisions, Truth (NZ) Ltd v Holloway ${ }^{135}$ and Blackshaw $v$ Lord, ${ }^{136}$ to justify its statement that "the law has been clear for many years that such allegations or complaints" 137 cannot be covered by qualified privilege. Two key difficulties emerge.

First, the cases cited by the Court are not directly in point. In Truth (NZ) a national newspaper alleged that a Minister improperly granted import licences. ${ }^{138}$ On appeal, the newspaper's claim of privilege was denied. The Court of Appeal ruled that defamatory statements of fact are not automatically privileged "merely because the general topic developed in the article is a matter of public interest." ${ }^{139}$ Blackshaw goes no further. ${ }^{140}$ The English Court of Appeal simply reiterated that "the nature of the matter published and its source and the position or status of the publisher ... must be such as to create the duty to publish the information to the intended recipients."141

Neither case directly excludes allegations of criminal conduct from qualified privilege. Indeed, to the contrary, obiter dicta in Blackshaw appears to support the application of qualified privilege to accusations of criminality in certain limited circumstances. ${ }^{142}$

${ }^{135}$ Truth (New Zealand) Ltd v Holloway [1960] NZLR 69 (CA).

${ }^{136}$ Blackshaw v Lord [1984] QB 1, [1983] 2 All ER 311 (CA).

${ }^{137}$ Vickery, above n 2, at [17].

${ }^{138}$ Truth (New Zealand), above n 135.

${ }^{139}$ Truth (New Zealand) Ltd $v$ Holloway, above n 131, at 83.

${ }^{140}$ Blackshaw, above n 132. The plaintiff sued for defamation after an article in The Daily Telegraph implied that he had been dismissed from the Civil Service for incompetence in relation to a government scheme which had wrongfully paid $\$ 52 \mathrm{~m}$ of taxpayer money to North Sea oil companies. No allegations of criminal wrongdoing were made, or inferred.

${ }^{141}$ At 327.

142 At 327. Stephenson LJ remarked that: "There may be extreme cases where the urgency of communicating a warning is so great, or the source of the information so reliable, that publication of a suspicion is justified; for example where there is danger to the public from a suspected terrorist or the distribution of contaminated food or drugs". 
Instead, the prohibition came from the two cases considered by the English Supreme Court: Purcell v Sowler ${ }^{143}$ and De Buse v McCarthy. ${ }^{144}$ In both cases, claims for privilege were denied, not because of the subject matter (allegations of criminal misconduct), but because publication was made to those without a proper interest or duty in receiving it. This leads to the second, more fundamental objection.

To the extent that previous authority precluded allegations of criminal impropriety from the protection of qualified privilege, this was not due to the underlying subject matter. Instead, the above cases simply reflect an application of the traditional duty/interest test. ${ }^{145}$ Where publication extended beyond those who had a proper duty/interest in receiving the information, qualified privilege was inapplicable. ${ }^{146}$ In contrast, Lange focuses on the community's public interest in receiving the information. ${ }^{147}$ As the Court of Appeal itself noted in Lange, reliance on the older authorities is inadvisable. ${ }^{148}$

In the author's opinion, the Court of Appeal's use of precedent is not compelling, and should not bar future relaxation of its strict approach.

\section{Trial by media}

Of greater concern to the Court of Appeal was the risk that mass publication of criminal accusations, before they have been properly investigated, would result in the denigration of the criminal justice system. ${ }^{149}$

This matter should not be taken lightly. ${ }^{150}$ The criminal justice system is specifically designed to recognise "the rights and legitimate expectations of those charged with

\footnotetext{
${ }^{143}$ Purcell v Sowler 2 CPD 215 (CA).

${ }^{144}$ De Buse v McCarthy [1942] 1 KB 156 (CA).

${ }^{145}$ Adam $v$ Ward, above $\mathrm{n} 6$.

${ }^{146}$ See also Templeton $v$ Jones, above $\mathrm{n} 7$.

147 Tobin, above $\mathrm{n} 120$, at 221.

${ }^{148}$ Lange 1998, above n 1, at 465 where the Court acknowledged that "the legal context [has] altered". Similar sentiments in the UK context can be seen in Flood, above n 3 at [58] - [60] per Lord Phillips, [117] - [119] per Lord Brown, and [171] - [178] per Lord Mance.

${ }^{149}$ Vickery, above n 2, at [19].

${ }^{150}$ For an example of extreme harassment by the press and severe invasion of privacy see $A v$ Norway [2009] ECHR 580.
} 
crime". ${ }^{151}$ These expectations are reflected in the highly structured nature of criminal proceedings. Defendants retain the right to remain silent, and procedural safeguards are employed to ensure a fair and accurate trial ensues. Underlying these protections is the presumption of innocence. ${ }^{152}$

The contrast with trial by press is stark. Allegations may be presented as if proved beyond reasonable doubt, leading readers/viewers, without further information, to believe in their truth. ${ }^{153}$ A person's reputation may be irreparably destroyed. Faced with blaring allegations, defendants will often feel the need to publicly respond, detrimentally affecting their subsequent criminal proceedings. ${ }^{154}$

Clearly, such developments are not in the public interest. Yet the statement quoted above represented the extent of the Court's reasoning on this point. ${ }^{155}$ The Court of Appeal failed to demonstrate how an extended Lange privilege would lead to subversion of the criminal justice process. It simply asserted that it would. This leads to the question - how realistic are trial by media fears?

\section{B How realistic are trial by media fears?}

Contrary to the Court of Appeal, it is argued that the existing Lange framework provides sufficient protection against trial by media to allow adoption of the Flood principle. Three considerations underlie this argument.

\section{Qualifying occasion}

First, Lange privilege is limited by the need for publication to be made on a qualifying occasion. As noted earlier, subsequent interpretation of this criterion has been limited. ${ }^{156}$ Nevertheless, while the Court of Appeal's use of the duty/interest test in Vickery was regressive, it demonstrates the importance of this requirement. It would be capable of

\footnotetext{
151 AP Simester and WJ Brookbanks Principles of Criminal Law (4th ed, Brookers, Wellington, 2012) at 25.

152 Simester and Brookbanks, above n 148, at 37. See also Woolmington $v$ DPP [1935] AC 462 at $481-$ 482, and the New Zealand Bill of Rights Act 1990, s 25(c).

${ }^{153}$ Flood v Times Newspapers Ltd, above n 30, at [104].

${ }^{154}$ Flood v Times Newspapers Ltd, above n 3, at [104].

155 See above, Section V Part B Subpart 2: A 'non-qualifying' occasion.

156 See above, Section V Part B Subpart 1: Publication on a "qualifying occasion".
} 
limiting Lange privilege to articles that appear considered, researched and of a sufficiently serious nature to justify publication of damning accusations. ${ }^{157}$

Flood and Vickery provide clear comparisons. Whereas three reporters spent six months considering the evidence against DS Flood, Vickery made little effort to investigate his claims of corruption. His evidence came from a single document that had been given to him, and previous investigation by the Auditor-General found no hint of criminal wrongdoing. In contrast, there was a strong circumstantial case linking payments to 'Noah' with DS Flood, coupled with an on-going police investigation. Given the reporters' concerns about the extent of the police investigation, publication served to place pressure on the police by bringing the investigation into the public eye. No such motivation is found in Vickery. There was no suggestion that the Auditor-General's report was flawed, nor any risk that the Serious Fraud Office would not conduct a thorough investigation. Finally, the article in Flood presented the plaintiff's denial and was "balanced in content and tone". ${ }^{158}$ Vickery simply asserted criminal suspicions.

\section{The relevance of malice}

More importantly, where plaintiffs can establish that the defendant was "predominantly motivated by ill will ... or otherwise took improper advantage of the occasion of publication", the prima facie privilege will be rebutted. ${ }^{159}$ This contains three further protections.

First, reporters who are "unable or unwilling to disclose any responsible basis for asserting a genuine belief in the truth" of their statements are prohibited from relying on their prima facie privilege. ${ }^{160}$ What amounts to a responsible basis "takes its colour from the nature of the occasion, and the nature of the publication." ${ }^{161}$ Reference to the Flood standard proves helpful. If adopted, defendants who assert that there are reasonable grounds to suspect the plaintiff committed an offence must "be reasonably satisfied both that the supporting facts were true and that there was a serious possibility" of guilt. ${ }^{162}$

\footnotetext{
${ }^{157}$ I use the word "appear" in this regard because questions of verification and author's motivation should primarily be addressed when considering s 19 of the Defamation Act 1992 and the improper use of the privileged occasion. In essence, it stands as a threshold enquiry.

${ }^{158}$ Flood, above n 3, at [180].

159 Defamation Act 1992, s 19(1).

${ }^{160}$ Lange 2000, above n 1, at [43].

${ }^{161}$ Lange 2000, above n 1, at [47].

162 Flood, above n 3, at [81] (emphasis added).
} 
Defendants who allege that the plaintiff is guilty must "satisfy [themselves], on reasonable grounds, that the claimant had in fact been guilty." "163 Only the most deserving defendants will live up to this standard.

Secondly, privilege is vitiated where there is an excess of publication. ${ }^{164}$ Gratuitous accusations of peripheral importance to carefully investigated articles will almost certainly fall outside Lange protection. ${ }^{165}$ In this regard, the scope of the privilege is limited to accusations which have been fully investigated, and have a clear link to the underlying story.

Thirdly, the journalist's motivations behind publication remain relevant. ${ }^{166}$ Lange privilege will not protect statements motivated by ill will, or which are designed to hurt the plaintiff rather than inform the public. ${ }^{167}$

\section{Contempt of Court}

Finally, where vitriolic comments or unrelenting media scrutiny interferes with the course of justice to the point whereby any future criminal proceedings may be jeopardised, criminal sanctions founded on contempt of court will be available. ${ }^{168}$ Although "illdefined", ${ }^{169}$ contempt actions will be sustained where criminal proceedings have already begun, or are "highly likely", ${ }^{170}$ and "as a matter of practical reality, [the media's coverage leads to] a real risk, as distinct from a remote possibility, of interference with a fair trial." ${ }^{171}$ Whilst this is a high standard, fears of criminal sanction will likely discourage the most unverified and vitriolic allegations from broadcast.

\section{Summary}

\footnotetext{
${ }^{163}$ Flood, above n 3, at [79].

${ }^{164}$ Lange 2000, above $\mathrm{n} 1$, at [39].

${ }^{165}$ Lange 2000, above $\mathrm{n} 1$, at [13].

${ }^{166}$ Lange 2000, above $\mathrm{n} 1$, at [43].

${ }^{167}$ See for example Chernesky v Armadale Publishers Ltd [1979] 1 SCR 1067, 90 DLR (3d) 321 (SCC) at 346.

${ }^{168}$ Flood, above n 3, at [197].

${ }^{169}$ Burrows and Cheer, above n 110, at 515.

${ }^{170}$ Television New Zealand Ltd v Solicitor-General [1989] 1 NZLR 1 (CA), at 3.

171 Solicitor-General v TV3 Network Services Ltd and Television New Zealand Ltd HC Christchurch M520/96, 8 April 1997.
} 
Although a decision by a five-member bench, the reasoning in Vickery $v$ McLean is at best difficult. Its use of precedent pre-dates the Lange expansion, while its discussion of trial by media lacks detailed reasoning and consideration. Moreover, as the foregoing analysis reveals, these fears are unlikely to be realised. In such circumstances, one hopes that future New Zealand courts will view Vickery as open to reconsideration.

\section{The case for change}

However, recognising that Vickery is open to reconsideration does not amount to a conclusion that it should be overturned. The impetus for change also comes from Vickery's non-compliance with the New Zealand Bill of Rights Act 1990 (BORA), and the weight of international authority.

\section{A BORA non-compliance}

Following the Court of Appeal's decision in Lange, it is clear that issues of qualified privilege must be considered within their "wider constitutional context." 172 Of particular importance is s 14 BORA which provides that "subject to such reasonable limits ... as can be demonstrably justified in a free and democratic society" 173

Everyone has the right to freedom of expression, including the freedom to seek, receive, and impart information and opinions of any kind in any form.

This is not an absolute right. It has long been accepted that freedom of expression cannot be used as a tool "to publish false and defamatory allegations about another." 174 Nevertheless, where it can be shown that "there is a greater public interest in freedom of expression than in protecting individual reputations", ${ }^{175}$ the law will provide protection in the form of qualified privilege. This is such an occasion.

Vickery's uncompromising stance represents an unjustifiable restriction on freedom of expression. In establishing its carte-blanche prohibition, the Court failed to acknowledge that, in at least two circumstances, the public interest in press revelations of alleged and

\footnotetext{
172 Lange 1998, above n 1, at 465.

${ }^{173}$ New Zealand Bill of Rights Act 1990, ss 5 and 14.

174 Jennings v Buchanan [2004] UKPC 36, [2005] 2 NZLR 577 at 584.

175 Lange 1998, above n 1, at 472 per Tipping J.
} 
unproven criminal accusations outweighs any resulting damage to the plaintiff's reputation.

First, it is widely recognised that freedom of expression is essential for the proper functioning of democratic government. ${ }^{176}$ In the English Court of Appeal's words: $:^{177}$

... the task of the electors under democratic institutions could not be satisfactorily performed if ... relevant information bona fide given were to be cut off by the fear of an action for libel.

Fully informed debate and evaluation requires the disclosure of all relevant information. By excluding accusations of criminal impropriety from qualified privilege, Vickery introduces an undesirable chilling effect into the law, undermining the Court of Appeal's ultimate desire in Lange to facilitate informed public discussion and evaluation of political figures. As Professor Burrows notes "[i]t would be ironic if wrongdoing so serious as to be criminal could never be disclosed to the voting public whereas lesser peccadillos could." 178

Secondly, qualified privilege plays a vital role in ensuring the media's ability to promote accountability throughout government, and society in general. It is well established that the press performs a vital function as a "bloodhound as well as a watchdog." 179 Investigative reporting may uncover information leading to an investigation, or as in Flood, ensure that an on-going investigation is completed thoroughly. Where complaints to public agencies have proven fruitless, recourse to the press may be the option of last resort for a person seeking an investigation. Such reporting and publication should be encouraged rather than constrained. ${ }^{180}$

\footnotetext{
${ }^{176}$ See for example Hosking v Runting [2005] 1 NZLR 1 (CA) at [267]; Coleman v Power and Others [2004] HCA 39, (2004) 220 CLR 1; Grant v Torstar Corp 2009 SCC 61, [2009] 3 SCR 640; New York Times Co v Sullivan 376 US 254 (1964); National Media Ltd v Bogoshi 1998 (4) SA 1196; and Reynolds, above $\mathrm{n} 9$.

${ }^{177}$ Braddock v Bevins [1948] 1 KB 580 (CA) at 590.

${ }^{178}$ Burrows, above n 125, at 218.

${ }^{179}$ Reynolds, above n 9, at 205. See also Grant v Torstar Corp, above n 173, at [52]; and Geoffrey Palmer and Matthew Palmer Bridled Power: New Zealand's Constitution and Government (4th ed, Oxford University Press, Melbourne, 2004) at 237.

${ }^{180}$ Burrows, above n 125, at 218. See also Jameel v Wall Street Journal Europe SPRL, above n 30, at [51].
} 


\section{B Comparable jurisdictions}

Significantly, the Court of Appeal's decision in Vickery swims against the tide of international authority. A brief survey of decisions from the United States, Australia and Canada reveals a generally accepted belief that, in certain circumstances, accusations of criminal impropriety are capable of protection through qualified privilege.

\section{The United States:}

In 1964, the US Supreme Court released its landmark decision in New York Times $v$ Sullivan. ${ }^{181}$ Barring proof of "actual malice", the Supreme Court held the Constitution conveys "an absolute, unconditional privilege to criticize [a public officer's] official conduct despite the harm which may flow from excesses and abuses." 182 Subsequent decisions extended this privilege to all public figures. ${ }^{183}$

This approach represents the highpoint of freedom of expression. Unless plaintiffs can prove that the journalist knowingly published false accusations or had a reckless disregard for the truth, all allegations of criminal conduct made against public officers or public figures is constitutionally protected.

\section{Australia}

Drawing inspiration from the Australian Constitution, the High Court of Australia, confirmed the existence of a defence protecting statements made "about political government and political matters." 184 This is more broadly defined than the New Zealand

\footnotetext{
${ }^{181}$ New York Times Co v Sullivan, above $\mathrm{n} 176$.

${ }^{182}$ New York Times Co v Sullivan, above n 176, at 298 (emphasis added). The scope of public officers is wide and includes senators, former mayors, deputy sheriffs, school board members, tax assessors and police officers. See Dwight L. Teeter Jr and Bill Loving Law of Mass Communications: Freedom and Control of Print and Broadcasting Media (12th ed, Foundation Press, New York, 2008) at 307.

${ }^{183}$ For example Curtis Publishing Co v Butts 388 US 130 (1967).

${ }^{184}$ Lange v Australian Broadcasting Corporation [1997] HCA 25, (1997) 189 CLR 520; 145 ALR 96 at 115. The existence of such a defence had already been considered in Theophanous v Herald \& Weekly Times Ltd (1994) 182 CLR 104, 124 ALR 1; and Stephens v West Australian Newspapers Ltd (1994) 182 CLR 211, 124 ALR 80.
} 
defence, and includes statements concerning Federal, State, Territorial and local level politics. ${ }^{185}$ However, this freedom to publish is qualified. ${ }^{186}$

Defendants must prove that their investigation and subsequent publication was "reasonable." 187 Whilst this depends upon all of the circumstances, two factors will be conclusive. First, the defendants must show that they took appropriate steps to verify to the point where they had "reasonable grounds for believing that the imputation was true". ${ }^{188}$ Secondly, the plaintiff's response must be sought and published "except in cases where the seeking or publication of a response was not practicable or it was unnecessary to give the plaintiff an opportunity to respond." 189

Nevertheless, even if the defendant can establish that publication was reasonable, where a plaintiff can prove that the defendant was motivated by malice (in the sense of "improper purpose"), the defence is defeasible. ${ }^{190}$

Subsequent statutory intervention, whilst not impeding the common law developments, appears to incorporate a Reynolds-like approach, with the additional inclusion of malice. ${ }^{191}$

Significantly, in Liu v The Age, ${ }^{192}$ the Supreme Court of New South Wales accepted that qualified privilege, at both statute and common law, is capable of covering serious allegations of bribery. ${ }^{193}$

\footnotetext{
${ }^{185}$ Lange v Australian Broadcasting Corporation, above n 184, at 116. The High Court of Australia also noted that "matters concerning the United Nations or other countries may be protected under the extended defence" at 115 .

${ }^{186}$ Lange v Australian Broadcasting Corporation, above n 184, at 113.

${ }^{187}$ Lange v Australian Broadcasting Corporation, above n 184, at 117.

${ }^{188}$ Lange v Australian Broadcasting Corporation, above n 184, at 117.

${ }^{189}$ Lange v Australian Broadcasting Corporation, above n 184, at 117.

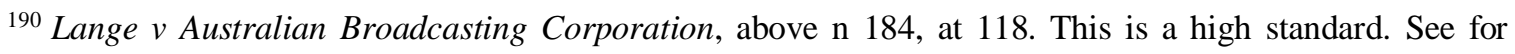
example Roberts $v$ Bass [2002] HCA 57, 212 CLR 1 at [104] and [107].

${ }^{191}$ For an example of the generic statutory provision, see s 30 of the Defamation Act 2005 (NSW) set out in the Appendix.

${ }^{192}$ Liu v The Age Co Ltd [2012] NSWSC 12.

${ }^{193}$ Liu, above n 192, at [154].
} 


\section{Canada}

In Grant v Torstar Corporation, the Canadian Supreme Court moulded a sui generis defence of "responsible communication on matters of public interest." ${ }^{194}$ Dispensing with the duty/interest analysis, ${ }^{195}$ the defence is significantly wider than the New Zealand and Australian approaches, and protects appropriately verified allegations relating to matters in the public interest. As with the UK, this two-step test leaves no room for the additional consideration of malice. ${ }^{196}$

Like Reynolds, the public interest is not limited to statements concerning government or political matters. "Nor is it necessary that the plaintiff be a "public figure"". ${ }^{197}$ It must simply be shown that a segment of society has a genuine interest in receiving the information. ${ }^{198}$ Indeed, the Supreme Court expressly acknowledged that allegations of "corruption or other criminality" may be in the public interest. ${ }^{199}$

Nevertheless, such serious allegations "demand more thorough efforts at verification than ... suggestions of lesser mischief." 200 The sufficiency of the reporter's efforts is assessed with reference to the seriousness of the allegation, its public importance, the status and reliability of the source, the urgency of the matter, and whether the plaintiff's side of the story was sought and published. ${ }^{201}$ Going one step further than Reynolds, there is no requirement that publication be balanced in tone or content. ${ }^{202}$ Instead: ${ }^{203}$

The best investigative reporting often takes a trenchant or adversarial position on pressing issues of the day. An otherwise responsible article should not be denied the protection of the defence simply because of its critical tone.

\footnotetext{
194 Grant, above n 176.

195 Grant, above n 176, at [95].

196 Grant, above n 176, at [192]. For the opposing position see Eugene C Lim "Malice, Qualified Privilege and the New Responsible Communications Defence to Defamation: Which Way Forward for Investigative Journalism in Canada?" UBC Law Review 223.

197 Grant, above n 173, at [106].

${ }^{198}$ Grant, above n 176, at [102].

${ }^{199}$ Grant, above n 176, at [111].

200 Grant, above n 176, at [111].

${ }^{201}$ Grant, above n 176, at [111] - [118].

${ }^{202}$ Grant, above n 176, at [123].

203 Grant, above n 176, at [123].
} 
Accordingly, Canadian jurisprudence is willing to protect adversarial reports of criminal accusations made against any person, so long as they are sufficiently verified and the information is in the public interest.

\section{Summary}

In the face of such authority, to which one could also add decisions from Hong Kong 204 and the European Court of Human Rights, ${ }^{205}$ it is clear that New Zealand represents the exception, rather than the norm. Coupled with Vickery's non-compliance with BORA, it is strongly suggested that, subject to the matters discussed below, New Zealand should adopt the Flood principle within the existing Lange framework. Doing so, would allow the publication of verified allegations of criminal conduct "which directly concern the functioning of representative and responsible government" or "the performance or possible future performance of specific individuals in elected public office". ${ }^{206}$ If the Lange framework subsequently expands (as is currently under consideration in the Court of Appeal ${ }^{207}$ ), so too should the protection given to the publication of criminal allegations.

\section{Three potential issues}

Although the Lange framework adequately guards against the risk of trial by media, encouraging the publication of criminal accusations leads to further risks. In particular, it must be shown that adoption of Flood will provide adequate protection for reputations, prevent media interference with on-going police investigations, and not undermine procedural safeguards.

\section{Adequate protection of reputation}

Accusations of criminality are easily made 208 and highly defamatory. Widely disseminated they have the potential to damage reputations forever. This is a real concern. It is not hard to imagine a situation where criminal accusations made by the media concerning a Member of Parliament may create such a frenzy as to force the MP

\footnotetext{
${ }^{204}$ Yaqoob v Asia Times Online Ltd [2008] 4 HKLRD 911 (Court of First Instance).

${ }^{205}$ See for example White $v$ Sweeden (2006) 46 EHRR 23, [2006] ECHR 42435/02, and Flux v Moldova (No 7) [2009] ECHR 25367/05.

${ }^{206}$ Lange 2000, above n 1, at [41]. See above Section IV Part B: Lange v Atkinson: the great leap forward.

${ }^{207}$ At the time of writing the Court of Appeal was considering an appeal from Dooley v Smith, above n 112.

${ }^{208}$ See for example Flood v Times Newspapers Ltd, above n 30, at [104].
} 
into retirement. ${ }^{209}$ If such allegations were later shown to be unfounded, then publication of the defamatory statement would have directly impinged on the functioning of "representative and responsible government" - exactly the opposite of the reform in Lange.

For defamation law to retain any relevance, the law must allow for the vindication of plaintiffs' reputations from such unjustified attacks. Flood provides such protection.

In particular, the news media remains attentive to threats of defamation. ${ }^{210}$ Not every call for an investigation will merit publication. ${ }^{211}$ Nor will every accusation of criminal misbehaviour result in an exposé. Expansion of Lange would simply allow these investigations to occur without the automatic risk of a defamation lawsuit. Reports will still need to be verified and, almost inevitably, the plaintiff's side of the story presented.

Two factors must be emphasised. First, as previously discussed, the level of verification demanded by Flood is not easily met. In over 10 years of Reynolds privilege, Flood represented the first time a national newspaper successfully relied upon a privilege defence. ${ }^{212}$ Almost inevitably plaintiffs will be able to establish that the journalists failed in their verification duties following publication of an incorrect article.

This provides the second protection. Defendants who are unable to establish the expanded Lange privilege remain liable in defamation. Given the highly defamatory nature of criminal allegations, the resulting damages are likely to be high. Accordingly, newspapers and other media are likely to self-regulate. Articles failing to meet internal verification standards are unlikely to be published.

\footnotetext{
${ }^{209}$ For an example of a situation where this result could have quite easily occurred see the Brendan Horan scandal at the end of 2012: John Armstrong, Adam Bennett and Claire Trevett "Horan 'doesn't know what the word wrong means"' (6 December 2012) The New Zealand Herald <www.nzherald.co.nz>. For an example of the news media's ability to influence an election see Ocala Star-Banner Co v Damron 401 US 295 (1971).

${ }^{210}$ Ursula Cheer "Myths and realities about the chilling effect: The New Zealand media's experience of defamation law" (2005) 13 TLJ 259.

${ }^{211}$ For example, in Vickery the New Zealand Herald never published Mr Vickery's letter of complaint.

${ }^{212}$ Hugh Tomlinson QC "Case Comment: Flood v Times Newspapers, Supreme Court allows "Reynolds" Appeal” (21 March 2012) The International Forum for Responsible Media Blog $<$ http://inforrm.wordpress.com>.
} 


\section{Interference with on-going police investigations}

Secondly, it has been argued that investigation by the media may interfere with on-going police investigations, thereby frustrating the purpose of bringing those who commit crimes to justice. ${ }^{213}$ Once again, the facts of Flood prove relevant. Although Tugendhat $\mathbf{J}$ held that there was no evidence to suggest that the press's inquiries had impeded the police investigation, ${ }^{214}$ there was some suggestion that, following a reporter's visit to ISC, several documents were shredded. ${ }^{215}$ Clearly, such interference with an ongoing investigation is not in the public interest.

Nevertheless, this argument fails to recognise that media investigations are just as likely to help, rather than hinder, an on-going police investigation. ${ }^{216}$ Journalists are often able to gather information more easily than the police. ${ }^{217}$ The additional publicity resulting from the media's publication of criminal accusations may encourage those with previously unknown information to approach the police. Moreover, where the press interferes with an ongoing investigation, the law provides a criminal sanction in the form of interference with justice.

\section{Use of defendant's statements in court}

Finally, as Moore-Bick LJ opined, many plaintiffs will feel the need to respond publicly. ${ }^{218}$ This may be to deny the accusations or to explain their behaviour. Nevertheless, if the allegations show merit, and the plaintiff is subsequently charged with a criminal offence, statements made in response to media questioning may form part of the prosecution case against them. In this regard, the media frenzy may serve to undermine the plaintiff's right of silence protected by BORA. ${ }^{219}$

\footnotetext{
${ }^{213}$ Mitchell, above $\mathrm{n}$ 44, at 27.

${ }^{214}$ Flood v Times Newspapers Ltd, above n 17, at [185].

${ }^{215}$ Flood v Times Newspapers Ltd, above n 17, at [81].

${ }^{216}$ For a situation where this occurred see Police v Campbell [2010] 1 NZLR 483 (HC); and Police v Campbell (No 2) [2010] 1 NZLR 509 (HC).

${ }^{217}$ Andrew Butler and Petra Butler The New Zealand Bill of Rights Act: A Commentary (LexisNexis, Wellington, 2005) at [13.24.5].

${ }^{218}$ Flood v Times Newspapers Ltd, above n 30, at [104].

${ }^{219}$ Bill of Rights Act 1990, s 25(d).
} 
Such fear is overstated. As Lord Dyson noted, plaintiffs can always deny the accusations, or seek legal advice before responding. ${ }^{220}$ If the media scrutiny is so substantial as to force a plaintiff into making comments detrimental to his/her defence, then sanctions founded on contempt of court may be available. In such circumstances, it is difficult to see why the actions of the plaintiff should restrict future development of Lange privilege.

\section{Conclusion: Redrawing the line}

This is a difficult problem. No answer is perfect. ${ }^{221}$

Faced with the difficult task of adequately balancing the right to reputation against the right to freedom of expression, courts must draw a line. New Zealand's current prohibition on publication of criminal allegations represents an unjustifiable restriction on freedom of expression, and goes against the liberalising reforms introduced by Lange. Adopting the Flood principle, within the existing Lange framework, provides a more appropriate balance. Doing so, will bring New Zealand into line with comparable jurisdictions whilst adequately safeguarding reputations and preventing fears of trial by media. If New Zealand courts subsequently expand the Lange framework, the protection given to publication of criminal allegations should expand correspondingly.

\footnotetext{
${ }^{220}$ Flood, above n 3, at [197].

${ }^{221}$ Reynolds, above n 9, at 201 per Lord Nicholls.
} 


\section{Bibliography}

\section{A Cases}

$1 \quad$ New Zealand

Dahya v Dahya [1991] 2 NZLR 150 (CA).

Dooley v Smith [2012] NZHC 529.

Hosking v Runting [2005] 1 NZLR 1 (CA).

Jennings v Buchanan [2004] UKPC 36, [2005] 2 NZLR 577.

Lange v Atkinson and Australian Consolidated Press NZ Ltd [1997] 2 NZLR 22 (HC).

Lange v Atkinson [1998] 3 NZLR 424 (CA).

Lange v Atkinson [2000] 1 NZLR 257 (PC).

Lange v Atkinson [2000] 3 NZLR 385 (CA).

Lee $v$ The New Korea Herald Ltd HC Auckland CIV-2008-404-5072, 9 November 2010.

Osmose New Zealand v Wakeling [2007] 1 NZLR 841 (HC).

McLean and Others v Vickery HC Auckland CP 283/97, 29 May 2000.

Police v Campbell [2010] 1 NZLR 483 (HC).

Police v Campbell (No 2) [2010] 1 NZLR 509 (HC).

Simunovich Fisheries Ltd v Television New Zealand Ltd [2008] NZCA 350.

Solicitor-General v TV3 Network Services Ltd and Television New Zealand Ltd HC Christchurch M520/96, 8 April 1997.

Television New Zealand Ltd v Solicitor-General [1989] 1 NZLR 1 (CA). 
Templeton v Jones [1984] 1 NZLR 448 (CA).

Truth (New Zealand) Ltd v Holloway [1960] NZLR 69 (CA).

Vickery v McLean [2006] NZAR 481 (CA).

2 Australia

Coleman v Power and Others [2004] HCA 39, (2004) 220 CLR 1.

Lange v Australian Broadcasting Corporation [1997] HCA 25, (1997) 189 CLR 520, 145 ALR 96.

Liu v The Age Co Ltd and Others [2012] NSWSC 12, (2012) 285 ALR 386.

Stephens $v$ West Australian Newspapers Ltd (1994) 182 CLR 211, 124 ALR 80.

Theophanous $v$ Herald \& Weekly Times Ltd (1994) 182 CLR 104, 124 ALR 1.

\section{Canada}

Chernesky v Armadale Publishers Ltd [1979] 1 SCR 1067, 90 DLR (3d) 321 (SCC).

Grant v Torstar Corp 2009 SCC 61, [2009] 3 SCR 640.

Hill v Church of Scientology of Toronto [1995] 2 SCR 1130.

Quan v Cusson 2009 SCC 62, [2009] 3 SCR 712.

4 European Court of Human Rights

A v Norway [2009] ECHR 580.

Flux v Moldova (No 7) [2009] ECHR 25367/05.

White v Sweeden (2006) 46 EHRR 23, [2006] ECHR 42435/02. 


\section{$5 \quad$ Hong Kong}

Yaqoob v Asia Times Online Ltd [2008] 4 HKLRD 911 (Court of First Instance).

6 United Kingdom

Adam v Ward [1917] AC 309 (HL).

Al-Fagih v HH Saudi Research \& Marketing (UK) Ltd [2001] EWCA Civ 1634, [2002] EMLR 13.

Blackshaw v Lord [1984] QB 1, [1983] 2 All ER 311 (CA).

Bonnick v Morris [2002] UKPC 31, [2003] 1 AC 300.

Braddock v Bevins [1948] 1 KB 580 (CA).

De Buse v McCarthy [1942] 1 KB 156 (CA).

Flood v Times Newspapers Ltd [2009] EWHC 2375 (QB), [2010] EMLR 169.

Flood v Times Newspapers Ltd [2010] EWCA Civ 804, [2011] 1 WLR 153.

Flood v Times Newspapers Ltd [2012] UKSC 11, [2012] 2 AC 273.

Horrocks v Lowe [1975] AC 135.

Jameel v Wall Street Journal Europe SPRL [2006] UKHL 44, [2007] 1 AC 359.

Loutchansky v Times Newspapers Ltd (Nos 2 - 5) [2001] EWCA Civ 1805, [2002] QB 783.

Purcell v Sowler 2 CPD 215.

Reynolds v Times Newspapers Ltd [2001] 2 AC 127 (HL).

Woolmington v DPP [1935] AC 462. 
7 United States of America

New York Times Co v Sullivan 376 US 254 (1964).

Curtis Publishing Co v Butts 388 US 130 (1967).

Ocala Star-Banner Co v Damron 401 US 295 (1971).

8 South Africa

National Media Ltd v Bogoshi 1998 (4) SA 1196.

\section{B Legislation}

New Zealand Bill of Rights Act 1990.

Defamation Act 1992.

Defamation Act 2005 (NSW).

Evidence Act 2006.

\section{Government Reports}

New Zealand Committee on Defamation Recommendations on the Law of Defamation: Report of the Committee on Defamation (Government Printer, Wellington, 1977).

Law Commission Defaming Politicians: A Response to Lange v Atkinson (NZLC, PP33, 1998).

Law Commission Defaming Politicians: A Response to Lange v Atkinson (NZLC, R64, 2000).

\section{Articles}

Ailbhe O'Neill "Reporting allegations: Reynolds privilege revisited in the UK Supreme Court” (2012) 47 Irish Jurist 185. 
Benjamin Barron "A Proposal to Rescue New York Times v Sullivan by Promoting a Responsible Press (2007) 57 Am UL Rev 73.

Bill Atkin and Steven Price “Lange 2000” [2000] NZLJ 236.

Brian Dowrick "Investigating Corruption - application of the Reynolds defence to print and on-line reports: Flood v Times Newspapers Ltd" (2010) 15 Comms L 116.

Brian Dowrick "Some Brief thoughts on Public Interest: Flood v Times Newspapers Limited" (2012) 17 Comms L 98.

Brid Jordan "The Modernization of English Libel Laws and Online Publishing” (2011) 14(7) Journal of Internet Law 3.

David Tan "The Reynolds privilege revitalised" (2013) 129 LQR 27. Eric Barendt "Reynolds Privilege and Reports of Police Investigations" (2012) 4 JML 1.

Eugene C Lim "Malice, Qualified Privilege, and the new Responsible Communications Defence to Defamation: Which Way Forward for Investigative Journalism in Canada?" (2012) 45 UBC L Rev 223.

Frederick Schauer “Uncoupling Free Speech” (1992) 92 Colum L Rev 1321

Geoff McLay "Lange v Atkinson: Not a Case for Dancing in the Streets" [2000] NZ Law Review 427.

John Burrows “Lange v Atkinson 2000: Analysis” [2000] NZ Law Review 389.

John Burrows “Media Law” [2002] NZ Law Review 217.

Jonathan Coad "Reynolds, Flood and the King's new clothes" (2011) 22 Ent LR 1.

Jordan R D Lester "Responsible communication on matters of public interest: An analysis of the modification to qualified privilege" (2012) 17 MALR 145. 
Kalvern "The New York Times Case: A Note on 'the Central Meaning of the First Amendment" (1964) S Ct Rev 191.

Paul Mitchell “The Nature of Responsible Journalism” (2011) 3 JML 19.

Peter B Kutner "Suspicion, Investigation and Truth: A Continuing Evolution in English Defamation Law" (2011) 3 JML 61.

Rosemary Tobin "Political discussion in New Zealand: Cause for Concern?" [2003] NZ Law Review 215.

Rosemary Tobin “Qualified Privilege in New Zealand: A Natural Progression?” [2000] NZ Law Review 415.

Tipping "The Harkness Henry Lecture: Journalistic Responsibility, Freedom of Speech and Protection of Reputation - Striking the Right Balance Between Citizens and the Media" (2002) 10 Wai L Rev 1.

Thomas D.C. Bennett "Flood v Times Newspapers Ltd - Reynolds Privilege Returns to the UK's Highest Court” (2013) 23 Ent LR 134.

Oliver Smith “Floodv Times Newspapers” (2010) 21 Ent LR 311.

Ursula Cheer "Defamation in New Zealand and Its Effects on the Media - SelfCensorship of Occupational Hazard?" [2006] NZ Law Review 467.

Ursula Cheer "Myths and Realities About the Chilling Effect: The New Zealand Media's Experience of Defamation Law" (2005) 13 Torts LJ 259.

WR Atkin "Defamation Law in New Zealand 'Refined' and 'Amplified"' (2001) Common Law World Review 237.

\section{E Books}

Andrew Butler and Petra Butler The New Zealand Bill of Rights Act: A Commentary (LexisNexis, Wellington, 2005). 
AP Simester and WJ Brookbanks Principles of Criminal Law (4th ed, Brookers, Wellington, 2012).

Basil Markesinis, Simon Deakin, and Angus Johnston Markesinis and Deakin's Tort Law (7th ed, Clarendon Press, Oxford, 2013).

Dwight L Teeter Jr and Bill Loving Law of Mass Communications: Freedom and Control of Print and Broadcast Media” (12th ed, Foundation Press, New York, 2008).

Geoffrey Palmer and Matthew Palmer Bridled Power: New Zealand's Constitution and Government (4th ed, Oxford University Press, Melbourne, 2004).

GHL Fridman Introduction to the Canadian Law of Torts (3rd ed, LexisNexis, Markham, Ontario, 2012).

Ian Loveland Importing the First Amendment: Freedom of expression in American, English and European Law (Hart, Oxford, 1998).

JF Burrows and Ursula Cheer Media Law in New Zealand (6th ed, LexisNexis, Wellington, 2010).

Kenneth S Devol Mass Media and the Supreme Court: the Legacy of the Warren years (2nd ed, Hastings House, New York, 1976).

Mark Warby, Nicole Moreham and Iain Christie Tugendhat and Christie: The Law of Privacy and the Media (2nd ed, Oxford University Press, Oxford, 2011).

Patrick Milmo and others Gatley on Libel and Slander (11th supp ed, Sweet \& Maxwell, London, 2011).

Patrick Milmo and WVH Rogers Gatley on Libel and Slander (11th ed, Sweet \& Maxwell, 2008).

Paul Rishworth and others The New Zealand Bill of Rights (Oxford University Press, Auckland, 2003).

Peter A Downard Libel (2nd ed, LexisNexis, Markham, Ontario, 2010). 
Stephen Todd and others The Law of Torts in New Zealand (6th ed, Thompson Reuters, Wellington, 2013).

\section{F Internet Materials}

Hugh Tomlinson QC “Case Comment: Flood v Times Newspapers, Supreme Court allows "Reynolds" Appeal" (21 March 2012) The International Forum for Responsible Media Blog <http://inforrm.wordpress.com>.

John Armstrong, Adam Bennett and Claire Trevett "Horan 'doesn't know what the word wrong means"' (6 December 2012) The New Zealand Herald <www.nzherald.co.nz>.

\section{G Magazine Article}

Jonathan Scragg and Polly Higbee "Qualified Privilege for Political Discussion Expanding the Scope?” NZ Lawyer (Wellington, 5 April 2013). 


\section{Appendix - Defamation Act (NSW) 2005}

\section{Section 30: Defence of qualified privilege for provision of certain information}

(1) There is a defence of qualified privilege for the publication of defamatory matter to a person (the recipient) if the defendant proves that:

(a) the recipient has an interest or apparent interest in having information on some subject, and

(b) the matter is published to the recipient in the course of giving to the recipient information on that subject, and

(c) the conduct of the defendant in publishing that matter is reasonable in the circumstances.

(2) For the purposes of subsection (1), a recipient has an apparent interest in having information on some subject if, and only if, at the time of the publication in question, the defendant believes on reasonable grounds that the recipient has that interest.

(3) In determining for the purposes of subsection (1) whether the conduct of the defendant in publishing matter about a person is reasonable in the circumstances, a court may take into account:

(a) the extent to which the matter published is of public interest, and

(b) the extent to which the matter published relates to the performance of the public functions or activities of the person, and

(c) the seriousness of any defamatory imputation carried by the matter published, and

(d) the extent to which the matter published distinguishes between suspicions, allegations and proven facts, and

(e) whether it was in the public interest in the circumstances for the matter published to be published expeditiously, and

(f) the nature of the business environment in which the defendant operates, and

(g) the sources of the information in the matter published and the integrity of those sources, and

(h) whether the matter published contained the substance of the person's side of the story and, if not, whether a reasonable attempt was made by the defendant to obtain and publish a response from the person, and

(i) any other steps taken to verify the information in the matter published, and

(j) any other circumstances that the court considers relevant.

(4) For the avoidance of doubt, a defence of qualified privilege under subsection (1) is defeated if the plaintiff proves that the publication of the defamatory matter was actuated by malice.

(5) However, a defence of qualified privilege under subsection (1) is not defeated merely because the defamatory matter was published for reward.

\section{The text of this paper, excluding footnotes, table of contents, appendix and the bibliography comprises 8000 words.}

